\title{
THE ANALYSIS OF REPETITION AS PART OF LEXICAL COHESION IN TALK SHOWS
}

\author{
Zia Hisni Mubarak. Universitas Putera Batam \\ mubarakzia@gmail.com
}

\begin{abstract}
Abstrak
Tujuan penelitian ini adalah menjabarkan lexical cohesion pada dialog. Adapun fokus penelitian ini adalah dengan melihat bentuk pengulangan yang sering terjadi dalam percakapan. Penelitian ini melihat telaah pada dialog dalam beberapa acara berbentuk talk show yang diambil dari youtube. Analisis kemudian diberikan terhadap data-data berupa dialog dari narasumber dan menyimpulkan temuan yang didapat. Penelitian ini sangat berguna terutama dalam hal membangun persepsi terhadap pendengar. Dari data yang telah dianalisis, peneliti menemukan bahwa kecenderungan pembicara adalah mengulang baik itu kata, frasa maupun kalimat yang terkadang pengulangan tersebut menjadi baik karena mempertegas sebuah pemikiran namun juga merugikan karena kalimat menjadi tidak efisien. Peneliti juga telah merangkum berbagai alasan pembicara melakukan pengulangan seperti misalnya untuk mempertegas penyampaiannya.
\end{abstract}

Kata Kunci: Pengulangan, Kohesi Leksikal, Talk Shows.

\section{INTRODUCTION}

When we encounter a new culture from different part of the world, we will find language within. Language can be a barrier to someone to communicate or it can be a way of success inlife. Someone who cannot interact to other by using the target language, of course, will be difficult to adapt later on. Meanwhile, for those who are able to speak the target language will have good relation to others.

In an interaction, the dialogue happens between two speakers or more. The dialogue is unique where each other try to deliver their idea and its meaning by using language that they understand together. To get the meaning, it is possible that someone sometimes repeat their words or sentences to stress what they intend to say to the interlocutor. This repetition is always happens in the dialogue.

One study that seems to be appropriate in analyzing the repetition is the discourse study. The analysis of discourse as Brown and Yule has explained asan analysis oflanguage in use, is always related to the text where discourse itself is a representation of a text. Meanwhile, Halliday and Hasan stated that the text is a study about language unit in use (Tanskanen, 2006).

In a discourse study, there are written discourse and spoken discourse. Both written and spoken are like two sides of coin where they are side by side as one unity of discourse, different but cannot be separated.A written discourse could be seen in the text of academic writing. The text that is produced in an academic writing is related to the academic setting. For example, a text, an essay, article, report, and so on. It is believed that in the written discourse, the words that is used in the sentence are varied than the spoken discourse.

Structurally and syntactically, written discourse is more complex than the spoken discourse. Written discourse is produced step by step through some processes of editing and revising. In contrast, spoken discourse is 
spontaneously produced without thinking about many rules in the language. It could be seen as in the dialogue (conversation) or monologue (speech). Both discourse, even though they are different, are interesting fact to be understood for someone who are willing to learn the language.

Based on the above understanding, this paper will try to analyzethe repetition as one part of lexical cohesion. Discussing about cohesion, it has some patterns where some meanings are expressed grammatically and the other one is expressed lexically. In grammatical cohesion, the meanings are expressed through reference, substitution and ellipsis. While in lexical cohesion, there are repetition or reiteration and collocation.

This paper has objective to find out how the repetition happened in a dialogue and to find out the reason of the repetition happened in a dialogue.This paper could also be a source of reading andguidance for the student who wants to conduct the research in the same area.

\section{REVIEW OF THE RELATED STUDIES}

Talking about cohesion is always related to the discourse analysis study. A discourse is socially situated and designed to achieve rhetorical goals (Swales in Bani-khaled, 2015). From other perspective such as a critical discourse analysis, discourse is defined as not a simply an isolated textual or dialogical structures (van Djik in Kurniawan \& Utami, 2017). Then, within the discourse, there is a study about cohesion and coherence where they are almost studied in the writing subject. Both cohesion and coherence are two indispensable aspect in a good writing (Patriana, Rachmajanti, \& Mukminatien, 2016). Cohesion and coherence are together forming a good writing where a coherent text is going to make sense to the reader and cohesion connects the elements of the essay one another.

Cohesion is defined as the linking phrases which aim to make the clear and readable text. In other words, it is a connection within phrases and sentences in the discourse itself(Bailey, 2006; Matthews, 2007; Renkema, 2004).Another definition is defined as the idea and meaning or semantic connection between sentences within a text where the non-structural text relation to the structural relation works together in forming a texture (Halliday \& Hasan, 1976; Hinkel, 2004; Taboada, 2004).Cohesion is specific to the text. But, it is not always related to the text, it is also related to the spoken discourse in the same way of the written discourse (Corssley \& McNamara,2016).It also help to link the idea in the text with some cohesion devices whether it is grammatical or lexical (Bae, 2001; Halliday \& Matthiessen, 2004; Knapp \& Watkins, 2005).

Cohesive devices consist of words and phrases to connect the sentences and paragraphs to make the ideas flow smoothly (Zemach \& Rumisek, 2003, 2005). There are various kinds of cohesive devices such as reference, lexical cohesion, and conjunction (Gerot \& Wignell, 1994); conjunction, reference, ellipsis (substitution), and lexical organization (Halliday \& Matthiessen, 2004); grammatical cohesion and lexical cohesion (Taboada, 2004); the use of conjunction and the link of phrases and sentences(Bailey, 2003); and substitution, ellipsis, reference, conjunction and lexical cohesion (Halliday \& Hasan, 1976; Renkema, 2004).

In lexical cohesion, there are repetition or reiteration and collocation. This paper study the repetition as a part of lexical cohesion where it is applied to make assumption from the speaker 
involved in a dialogue in the spoken discourse context and the dialogue is converted into a written discourse.

\subsection{Review of the Related Findings}

In order to support this paper, some studies had been conducted earlier about the discourse in a context. Sakhiyya (2017) focused on the relationship between question and social identity by employing critical discourse analysis in investigating the construction and negotiation of social identity through questions. The negotiation of identity through questions is evident from the emerging patterns of the length of the interrogative form, repetitive questions, and the intensity of social control.

Another study is about writing abstract where the article attempts to reveal the coherence of the abstracts of the final project reports of the undergraduate students of PGRI University Semarang, Indonesia. Several abstracts of the students' final projects were selected randomly to be analyzed. The result shows that the abstracts analyzed have not satisfactorily achieved coherence though some cohesive devices like reference, conjunctions, ellipsis which are used to link one sentence to the other. Some grammatical mistakes are also found such as the plural forms, active-passive voice (Suwandi, 2016).

Furthermore, Manipuspika

conducted a research about coherence in a talk show. She tried to show how conversational coherence is achieved within talk shows, what strategies used by both host and interviewee to achieve coherence collaboratively. It was shown that in both English and Indonesian talk shows, conversational activity of asking questions can be employed to measure a coherence of a stretch of conversation.

After that, Mubarak (2013)evaluated the students' ability in building cohesion and coherence in argumentative essays where the ability was Low Average. This condition happened due to the lack of understanding about cohesion and coherence theory. This could be happened because of many factors such as lack of awareness to understand the theory well.

Ellis (2005)examined the cohesiveness of descriptive discourse from individuals who had suffered a left-hemisphere stroke and had not been diagnosed with expressive language impairment. The analysis began from a month, sixth month, and a year after getting a stroke. The findings indicate that cohesive ties in descriptive discourse remained generally constant during the first year post-stroke, the percentage correct use of cohesive ties increased significantly during the same time period.

At last, Yeh (2004) analyzed several Chinese texts with a focus on the use of reference and conjunctive relations. The analysis shows that cohesion, as surface linguistic features, cannot account fully for the coherence of a text. Rather, underlying semantic relations as well as readers' perceptions of the text should be taken into consideration to construct a complete picture of discourse processing.

\section{RESEARCH METHOD}

The design of this research is a descriptive research which involved the collecting of the data (information)from a variable, indication and condition in order to answer the research questions concerning the current status or phenomena (Arikunto, 2010). In other words, the fact that happens now is 
explained by using qualitative approach since descriptive research seeks to probe deeply into the research setting to obtain in-depth understandings about things as the way they are (Gay, Mills, \& Airasian, 2009).

The population and sample in this paper are called subjects of the research (Satori \& Komariah, 2011).The subject of the research is the dialogue from talk show where it is downloaded fromyoutubeby using purposivesampling technique(Gay et al., 2009).Then, the data is downloaded from the YouTube channel to be listened and written into transcript. After that, there are some processes to analyze the dialogue such as reading the transcript and underline or highlight the sentence whether it presents the indicators of lexical cohesion or not,and analyzing and evaluating the lexical cohesion in the dialogue.

\section{DISCUSSION}

The researchers identified some repetition on the dialogue based on the understanding of lexical cohesion, reiteration and collocation. This paper brings reiteration as the subject of analysis. The types of reiteration which is emphasized in this research is the repetition of the exactly same item or rephrased (Taboada, 2004).

(1) E: I Cannot tell you I/ah//or/ thank you enough for what you have done for the gay community, so thank you.

From (1), it is clear that the speaker $\mathrm{E}$ has repeated the phrase "thank you"to express her deepest gratitude to the guest on her show. She repeated that phrase "thank you"to make sure that her gratitude is accepted by the guest speaker O. She said "thank you"in the beginning of the sentence and emphasized it in the last one. This repetition is categorized as the exactly same item repeated; "thank you". The reason why she made this repetition because it could be analyzed from the context of their situation on that time where the guest speaker Owas the President of the United States of America and the speaker E as one of the influential figure for the gay community. By his support, the gay community had their freedom to choose their way of life. To represent the gay community, she expressed the deepest gratitude by repeating the phrase "thank you"to him.

(2) O: You know it was /ah/ it was one thing...

The guest speaker $\mathrm{O}$ repeated the phrase "it was"two times. He repeated the same item as previous item. The type of this repetition is the exactly same item repetition. He repeated the phrase because he intended to respond the previous talk from the speaker E. This repetition is to stress the expression to convince the interlocutor that he was really serious to support the community.

\section{(3) O: ... How do we bring more, more people...}

In (3), the guest speaker $\mathrm{O}$ repeats the word more. The word "more" is repeated exactly in the same item as it appeared firstly in the sentence. The word "more" is added after the same word "more", it looks like a repetition in the written context. But in this context, the speaker does not have any special intention to stress what does he mean but it is only natural repetition where in the time of he speaks, the situation is not too formal, without using any concept or script for speech, and it is purely his own thought based on his background knowledge. Why did he do the repetition? It was 
unnecessary repetition actually because he repeated the word "more" to recall his memory.

\section{(4) O: ... I really mean that. That's true.} That's true...

The guest speaker $\mathrm{O}$ repeated the same item in the end of this sentence "that's true". His intention is clear that to show to the speaker $\mathrm{E}$ that what he has said is deeply through his heart. As politician, if he intended to compliment something in front of people, he would say what it has to be said about the fact or the reason. In that context, he compliment the speaker E for something that he could not do as she did with her ways.

(5) O: ... you were then suddenly... and then suddenly it is ...

In (5), he gives another intention to his repetition. He still repeat the same item of phrase "then suddenly". Actually, this is unnecessary repetition too. The phrase "then suddenly" shows that the speaker does not want to have miss perception to his words.

(6) $\mathrm{O}:$... it's your co-worker $\underline{\text { and }}$, and, and then ...

Both (5) and (6) are the repetition of the same item where those repetitions are redundant of the same word. In a formal writing, this is unnecessary to be written because they are meaningless. But in the informal situation, the repetition sometimes occurs accidentally. The reason why the speaker intended to repeat some words or phrases because he wants to give a little time to think about the right things to be said to express his ideas or thoughts. From (1) to (6), the data shows that the guest speaker $\mathrm{O}$ keep repeating his words or phrases in a form of repetition of the same item.
Another data is taken from other talk show of the speaker JF and guest speaker Z. The repetition on this dialogue is a little bit different to the previous data where the repetition comes from the speaker JF and then it is repeated by the guest speaker $\mathrm{Z}$ as it is shown in (7).

(7) JF: ... got nominee for three golden globes, today. Z: Today

In this dialogue, the repetition is happened after the speaker JF said it and directly repeated by the guest speaker $Z$. The repetition is the same itemrepetition, where the word "today" is repeated exactly the same as the previous one. In this context, the guest speaker $\mathrm{Z}$ repeated the word "today" after JFbecause she wanted to show her feeling about what she has gotten with the movie where she got nominee for three golden globes. She is surprised by the opening sentence of the talk show. He actually wants to remind her about the success of the movie for being nominated. In other words, he is trying to say that her movie is great and everyone should watch it.

Another data shows that the repetition happened between two speakers again. Firstly, the speaker JF said the sentence and it was repeated by the guest speaker $\mathrm{Z}$ and repeated once more time by the speaker JF, see the dialogue below:

(8) JF: That's a big deal!

Z: That's a big deal!

JF: That's a big deal! ..

The repetition is once again repeating the same item where the sentence "That's a big deal!" is repeated two times after the first sentence. This repetition could be happen in the dialogue. The guest speaker $\mathrm{Z}$ as one who got nomination for three golden globes for her movie was still in surprise and she had a beautiful 
feeling about her future. That is why in the dialogue, she responded responsively and smile a lot in front of the camera.

(9) JF: ... What was the training like, you mean?

Z: I mean...

This repetition is repeating the same item but there is a little change in the subject from the phrase it is being repeated. The phrase "you mean" which is stated by the speaker JF is repeated differently by the guest speaker $\mathrm{Z}$ " $I$ mean" in the form of its subject only. The pronoun "you" and " $I$ " refers to the guest speaker Z. Both phrases are still the same in the context of meaning but it is structurally different.

(10)Z: So amazing.

Z: So amazing he is gonna be huge.

(11) Z: ...I don't have it anymore. I don't have it anymore.

In this dialogue, the repetition happens in one speaker only. The first phrase is "so amazing" but then it is repeated again by the guest speaker $\mathrm{Z}$ with an additional information "so amazing, he is gonna be huge". The kind of the repetition is still repeating the same item with the additional information. She also repeats the same item of sentence as in (11) and repeat it once to make sure about her words in front of the audiences.

\section{(12) JF: ... that was different time.}

\section{Z: But it was different time, it was different time.}

This repetition occurs when the speaker JF said "that was different time" and repeated by the guest speaker $\mathrm{Z}$ with "it was different time" two times. The repetition is still repeating the same item with different pronoun where the speaker JF refers to the specific time with the subject "that" and the guest speaker Z repeats it with the other subject "it".

\section{(13)Z: But it was different time ... $\underline{\text { Butit wasit }}$} was a lot of training

In (13), the first repetition is conjunction.

The function is to connect two phrases or sentences. The conjunction "but" is repeated in the second sentence. If we take a look at the context of the dialogue, it is unnecessary to put it in the beginning of the sentence because it does not show the cause effect relation. The conjunction might be as the stressing of different time they have discussed earlier. While the phrase "it was" is literally repeated as the same item repetition where probably the speaker hesitated about something.

\section{(14)Z: ... and there was no net. \\ $\mathrm{Z}$ : No nets. $Z$ : ..., they did nothave those yet. So, I was, I was hookedup on ...}

In (14), the guest speaker $\mathrm{Z}$ repeats the sentence into a phrase. The sentence “... and there was no net" is repeated into a short form of phrase "No nets". This repetition is kind of rephrased repetition. In the first sentence, she claimed it in singular noun "was no net" but suddenly it is changed into plural form " $n o$ nets". Probably the guest speaker $\mathrm{Z}$ wanted to show to the audience that the building was empty without any single safety net. After that, she also rephrased the phrase back into sentence again, that is "they did not have those yet". In addition, still in the same context of her speaking, she also repeat the unnecessary repetition, that is the phrase "I was" where she intended to stress her condition on that time and want the audience to pay attention to her story. 
(15)Z: ..., you're bad ass. And Iwas like, take me up.

JF: take me upI can doI can do it easily.

$\mathrm{Z}$ : take me up.

JF: I can do it easily.Huge Jackman

called you bad ass, ...

Z: Huge Jackman called me as bad ass.

From the part of dialogue (15), there are some repetitions happen. The sentence "you're bad ass" from the guest speaker $\mathrm{Z}$ is repeated by the speaker JF with "Huge Jackman called you bad ass" and it is reapeted also by the guest speaker Z herself with "Huge Jackman called me as bad ass".In this repetition, the source sentence "you're bad ass" is rephrased into some other sentences. After that, the phrase "take me up" is repeated in its source phrase by them as well. The repetition is the same item repetition. Finally, the speaker JFadds other information commenting on the speaker JF and the guest speaker Z's phrase "take me up", that is the sentence "I can do I can do it easily" where he repeats the sentence "I can do" two times before he adds adverb of manner "easily" to explain it in details.

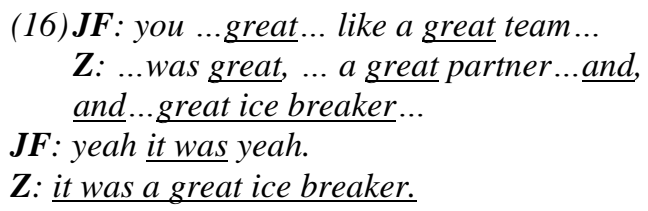

From (16), there are some repetitions of word "great" in the dialogue. Literally, the word "great" is repeated in the same form of its source but the context would be different. If we see the context of the above dialogue, great chemistry and great team were repeated in other form of sentence. It is a kind of rephrased repetition where both phrases are turned into some sentences which explained about great chemistry and great team. The other repetition could be seen from repeated conjunction "and" where it is unnecessary repetition. At last, there is rephrased repetition where the phrase"great ice breaker" is turned into another phrase "it was" and "it was a great ice breaker".

(17)JF: That's how you do it. That is how you do it. Zendaya everybody.

In (17), the speaker JF repeats his own sentence "that's how you do it" to express his salutation to the guest speaker $\mathrm{Z}$ after seeing the real video clip of her. In this repetition, the same item repetition occurs. Then, these following data are taken from the speaker $\mathrm{E}$ and the guest speaker MO.

(18) MO: It's my pleasure, I love you $\boldsymbol{E}:$ I love you too

This type of repetition is repeating the same item where the sentence "I love you" is repeated by the speaker E. The reason to repeat this sentence could be to show that the guest speaker MO has the same feeling as the speaker E.

(19) MO: and you look great! Look at you, ...

E: Well look at you

MO: look at your shoes

In this repetition, the phrase "look at you" is repeated by speakerE and the guest speaker gave comment by repeating it with different object "look at your shoes".

(20)MO: look at your shoes

$\boldsymbol{E}:$ Well I have shoes on

MO: You got shoes on,

E: I know I got shoes on

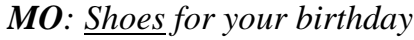

In (20), the word "shoes" is repeated many times by both speakers and the sentence "You got shoes on" is repeated by pronoun modification of subject you and I. Both (19) and (20) are repeating the same item of word and phrase. The reason why the speakers did these repetitions could be as greetings and jokes as an ice breaker. By giving each other compliments, 
the atmosphere in the shows will be easy going and relax.

\section{(21)E: What did you do? \\ MO: Nothing}

$\boldsymbol{E}:$ Nothing?

In (21) the repetition is the same item repetition where the word "nothing" is repeated. In this context of the dialogue, the speaker $\mathrm{E}$ was curious about what did the guest speaker MO do after leaving the White House. The guest speaker MO responds "nothing" and the speaker E replied the same word to question about her word. In (22), another repetition occurs.

(22)MO: Came out of the basement! It's just like. What? Come out of the house? But we're, we're we're doing great!

The first sentence of the guest speaker MO that is "came out of the basement" which is repeated with the other object "come out of the house". Basement and house are two related nouns where the basement is usually found in the house. We can say that the basement is a part of the house. The repetition here is repeating the same item with different object. While the other repetition such the words "we're" are repeated two times. The repetition is still the same item repetition but it is unnecessary repetition where there is no meaning of repeating those words. The repetition such this one could be happen because the speaker was thinking about the idea of what she is going to say.

\section{(23)E: I'm ...challenge you to...}

MO: Yeah I'm not dressed for challenge $\boldsymbol{E}:$ I'm not either and I'm not

The dialogue (23) has both repetitions. The word "challenge" is repeated. This is the same item repetition, while the other repetition is kind of rephrased. The sentence "Yeah I'm not dressed for challenge" is repeated by both speakers; that is "I'm not either and I'm not". That sentence refers to the word "challenge". The context within the sentence is still about the word "challenge" in the first appearance.

\section{(24) MO: and I'm gonna beat you anyway}

\section{$\boldsymbol{E}:$ I bet you would}

The guest speaker MO said "I'm gonna beat you anyway" is rephrased by the speaker E with her answer "I bet you would [beat me]". In this phrase, speaker E omits the object since the context is already clear. By omitting some unnecessary words, the sentence will be more efficient. But it is different with the sentence from (25).

\section{(25)MO: I have to, I have to.}

You gotta change your work-out

In (25), the guest speaker MO repeats the phrase "I have to" one time with the same word. It is the same item repetition. In this context, it is showing that she is enthusiastic with the previous words from the speaker E.

(26) E: I know you have arm MO: My arms are so much longer than yours, it is all go down

The speaker E speaks about "arm", the guest speaker MO repeats the word "arm" but with different class of words. The speaker E refers it with singular noun but the guest speaker MO changes it into plural nouns. After that, the guest speaker MO does the second types of repetition, rephrased repetition. The guest speaker MO rephrased the word "arms" with pronoun "yours". The pronoun is obviously referring to the subject of reference.

(27) MO: That was eight years ago E: $\underline{\text { Just,just coz that was eight }}$ Yearsago, I wasn't shape in, $\underline{I}$ was, Iwasn't sixty... 
The guest speaker MO says "eight years ago" and it is repeated by the speaker E with the same sentence. Speaker E does repetition such as the word "just", and "I was" which become "I was not". Those repetitions are repeating the same item repetition.

(28) MO: We, we're living in Washington /yup/ /yup/we're staying in Washington...

In (28), the repetitions are still the same item repetition, but there is a little bit altering in the structure of the sentences such as the word "we" is repeated and changed into "we're". After that, the second repetition is in the sentence "we're living in Washington" is repeated by using another verb "we're staying in Washington".

(29) MO: No it is not.

E: No?

MO: Yeah, no it's not. I ...eight years... and we, we're in the White House for eight years but ....

(30)MO: ... I have a door and a door bell, ... my door and ... doorbell is, so the doorbell ring and ...

\section{(31)E: Coz Malia is not there} MO: Malia's not, she ....

(32) $\boldsymbol{E}:$..., I, I...his wife were, were moving ...

The repetitions of the same item almost occur in the dialogue. The dialogue from sample (29), (30), (31), and (32) are representing repetition of the same item. In (29), the first repetition of "no, it is not" is repeated exactly the same. After that, the phrase "eight years" is also repeated using the same phrase. Then, the subject " $w e$ " is repeated by adding its verb into "we're". In (30), the words "door" and “doorbell" are repeated many times. In (31), the subject "Maliais not" is repeated by the guest speaker MO. Finally, in (32), the repetitions are related to the pronoun reference and the verbs.
The reasons why the speakers repeat their words, phrases, or sentences because in this context, those speakers want convince their idea to the audiences that what did they tell about is important thing as the lesson.

\section{(33) E: there was box given}

MO: the Tiffany's box

$\boldsymbol{E}:$ yeah $S o$, what was in there?

MO: It was a lovely frame,

$\boldsymbol{E}$ : what? A frame

MO: it was a frame, ...

In (33), the words "box" and "frame" are repeated many times as the same item repetition. The repetition of the word "box" is also involved the pronoun reference as the words "there" and " $i t$ ". These repetitions could be happened because the speakers want to speak efficiently and want the message is delivered without any trouble.

(34)MO: ...you,you gonna ... this gift so... what, what ... this gift and everyone clear out and... the box then .... cleared out, ... box...

(35) E: I ... my gift? MO: ...gift, Oh my,oh my...

In (34), the repetition happened as the words "gift, box and clear out" repeated normally. It is also the same condition as in (35) where the word "gift" is normally repeated by the other speaker. Those are as previously stated are the same item repetition as well. While the others such in (34), the words "you" and "what" are repeated as the same item repetition but those repetitions are unnecessary. The same thing as in (35), where the word "oh my" is repeated closely. Because these repetitions are not normal, they are meaningless. But these repetitions could help the speaker to think about the proper idea to be spoken. They are like pauses which function to recall the memory about something. 
(36) MO: I ... of Wine

MO: You ...wine

MO: ...to keep, to keep you flowing, you know and you know...

(37) MO: you gonna re-gift?

E: I'm gonna re-giftnext year ...

(38)E: Oh no. who knew they made it? MO: Who knew? ...

(39)MO: You put it in the water E: you water it

Some repetitions that occur in (36), (37), (38), and (39) are all the same item repetition type. The source words are repeated as the target words. In (36), the word "wine" is repeated normally but the words "to keep" and "you know" are repeated unnecessarily. Those repetitions are unnecessary because they are meaningless. In (37), the word "re-gift", the word "who knew" in (38) and the word "water" in (38) are normally repeated as the same item repetition. These normal repetitions are needed in order to make the context clear and understandable. But for those words which are not normally repeated happen could be because the condition of the speaker itself.

These following data are taken from the speaker JF and the guest speaker BG. In this context of the dialogue, they are talking about the invention for Africa.

\section{(40) JF: ... The Omni.... \\ BG: Processor. \\ JF: Omni-Processor.}

The speaker JF hesitates what to say about the guest speaker BG invention that is "the OmniProcessor". Then after getting the information from the guest speaker BG, he makes repetition to strengthen his information to be delivered to the audience. The repetition is repeating the same item of words, phrases, or sentences.

(41)BG: ... take sewage and ... of sewage coz sewage is bad ... that sewage.
$J F:$ and you, you, you change it into water that drinkable water?

In (41), the word "sewage" is repeated many times without changing it with the pronoun reference. The speaker here seems to show that the bad thing that he mentioned could be full of benefits. He repeated that word to convince the audience that he is really serious in paying his attention to the waste like sewage. Then, the word "water" is also repeated by the other speaker to make sure whether the water from the bad thing such sewage could become a good water or remain the same. The last repetition is the word "you" which is repeated by the speaker $\mathrm{JF}$ because he is amazed and does not believe to what he has heard from the guest speaker BG. Actually, the last repetition is unnecessary because it is meaningless. All repetitions are included into the same item repetitions.

(42) BG: ... you got sewage ...

$J F$ : you got sewage.

BG: ...water and it is good water.

JF: ... we actually had two glass of water.

(43)JF: ... one is the sewage water ... is sewage was, but we're gonna, we're gonna drink and then, and thenwe're gonna see and ... is sewage.

BG: $\underline{\text { You bet. }}$.

JF: Yeah, you do, you do bet.

From (42) and (43), the repetitions happens in some ways. In (42), the word "you got sewage" is repeated normally by the speaker JF. He intends to make sure that sewage remains sewage and never going to be changed into a good water, so that is why he repeats to cut the sentence of guest speaker BG. Then, the word "water" is repeated to convince the speaker JF that the sewage can be a good water with a proper treatment. Then, in the next turn,the speaker JF repeat that word again to offer both of them the filtered sewage water. Meanwhile, in (43), the word "sewage" is repeated to convince 
himself (the speaker JF) which one is the sewage water which one is not [in this context the bottle water]. After that, the phrases "you're gonna" and "and then" are repeated because he is nervous and hesitates about his choice. By repeating some unnecessary phrases, he wants to show the audiences that he has a big doubt about the water. Furthermore, the guest speaker BG tries to calm down him by saying the word " $b e t$ " where they have two glass of water, one contain sewage filtered water and the other is bottle water. The speaker JF could choose one of them. To avoid his nervous, the speaker JF repeat that word by adding do to emphasize that he is really sure. All the repetitions in (42) and (43) are the kinds of repeating the same item repetition.

\section{(44)BG: you bet to pick.}

JF: yeah I know, I got to pick right?

The repetition happens in (44) is the rephrased repetition where the speaker JF repeated what the guest speaker BG said in a different structure of the sentence. This condition could happen when one of the speaker in that dialogue is nervous. In this context, the speaker JF is nervous and hesitates to choose the water.

$$
\begin{aligned}
& \text { (45)BG: Alright } \\
& \text { BG: } \frac{\text { alright }}{\text { JFight }} \\
& \text { BG: }: \text { there you go. } \\
& \text { JF: alright. } \\
& \text { BG: } \underline{\text { cheers. }} \\
& \text { JF }: \text {..., } \underline{\text { cheers. }} . \text { One, two, three. }
\end{aligned}
$$

Both speakers repeated the same words two or three times such as the word "alright" and "cheers". Those are still the same item repetition. From the context, this repetition shows how much nervous the speaker JF is while the guest speaker BGis relax because he knows the truth.
(46) JF: I'm pretty confident that, that was.

BG: well ... Was all poop water?

JF: that was both a poop water?

The speaker JF repeats the connector "that". The repetition is meaningless because it does not have any meaning. The intention could be because he was not sure about his choice or he was nervous after drinking the water he has chosen. Then, the guest speaker BG reveals the truth that both glass was "poop water" and also repeated by the speaker JF to make sure that the guest speaker BG is not serious. Both repetition are in the form of the same item repetition.

(47)BG: the machine, the machine, the machine is pretty miraculous.

In (47), the guest speaker BG wants to emphasize that the water becomes drinkable water because of the machine he has create with the engineers. He repeated the word "machine" two times to convince the speaker JF and audience that the machine works very good and can produce a good water from the sewage water.

\section{(48)JF: I gotta to give up, I gotta to give up.}

This sentence is repeated by the speaker JF to give his salutation toward what the guest speaker BG has done with the sewage water so that it becomes drinkable water and taste good like the bottle water. The sentence "I gotta to give up" means he does believe towards the guest speaker BG achievement on that sewage water. The sentences are repeated by using the same item repetition.

From the data analysis, it could be said that almost speakers in the sample of this research tend to repeat the same words in a spoken communication. As Taboada, (2004) explains that she has impression that the 
speakers tend to repeat the same terms. It means, in speaking, the speakers tend to repeat a word, phrase or even sentence in a communication.

\section{CONCLUSION}

After discussing the data, it has been found that most of speakers tend to repeat wheter it is the word, phrase, or sentence with the same terms through the same item repetition. It is likely that this kind of repetition looks easier.The other repetition is also found, that is rephrased repetition where only few data has been found this kind of repetition.

It has been found also that the reasons why did they repeat their word, phrase or sentence in a dialogue. The reasons such as to express the deepest gratitude, to respond the previous talk, to recall memory, to tell the truth, to show feeling, make sure about the intention, does not want to have miss perception and probably the speaker hesitated about something.

\section{REFERENCES}

Arikunto, S. (2010). Prosedur penelitian: Suatu pendekatan praktik. Jakarta: Rineka Cipta.

Bae, J. (2001). Cohesion and Coherence in children's written English: Immersion and English-only classes. Regents of the University of California, 12(1), 51-58.

Bailey, S. (2003). Academic writing: A practical guide for students. New York: Routledge Palmer.

Bailey, S. (2006). Academic writing: A handbook for international students (Second Edi). New York: Routledge.

Bani-khaled, T. A. A. (2015). A discourse study of the speech "It can be otherwise" by Harvard professor and president Drew Faust. International Journal of Linguistics, $\quad 7(6), \quad 1-18$. https://doi.org/10.5296/ijl.v7i6.8372

Corssley, S. A., \& McNamara, D. S. (2016). Say more and be more coherent: How text elaboration and cohesion can increase writing quality. Journal of Writing Research, 7(3), 351-370. https://doi.org/10.17239/jowr2016.07.03.02

Ellis, C. E. al. (2005). Recovery of cohesion in descriptive discourse after lefthemisphere stroke. Journal of Rehabilitation Research \& Development, 42(6), 737-746.

Gay, L. ., Mills, G. E., \& Airasian, P. (2009). Educational research: Competencies for analysis and applications. New Jersey: Pearson Education.

Gerot, L., \& Wignell, P. (1994). Making sense of functional grammar: An introductory workbook. Sydney: Gerd Stabler.

Halliday, M. A. ., \& Hasan, R. (1976). Cohesion in English. London: Longman Group Limited.

Halliday, M. A. K., \& Matthiessen, C. (2004). An Introduction to functional grammar (3rd edition). London: Arnold.

Hinkel, E. (2004). Teaching academic ESL writing: Practical techniques in vocabulary and grammar. New Jersey: Lawrence Erlbaum Associates, Inc.

Knapp, P., \& Watkins, M. (2005). Genre, text, grammar: Technologies for teaching and assessing writing. Sydney: UNSW Press.

Kurniawan, E., \& Utami, A. D. (2017). The representation of Joko Widodo's figure in the Jakarta Post. Indonesian Journal of Applied Linguistics, 6(2), 341-350. https://doi.org/dx.doi.org/10.17509/ijal.v6 i 2.4918

Manipuspika, Y. S. (2014). Accomplishing coherence in talk shows: A comparison between English and Indonesian. Indonesian Journal of Applied Linguistics, 3(2), 154-168.

Matthews, P. . (2007). The Concise Oxford Dictionary of Linguistics. Oxford: Oxford University Press.

Mubarak, Z. H. (2013). An Analysis of Students' Ability in Building Cohesion and Coherence in Argumentative Essays Written by the Fourth Year Students of 
English Department at University of Bengkulu. English Language Teaching, 1(3), 30-42.

Patriana, A. W., Rachmajanti, S., \& Mukminatien, N. (2016). Students' ability in using discourse markers to build coherence in compositions. TEFLIN Journal, 27(2), 203-216. https://doi.org/dx.doi.org/10.15639/teflinj ournal.v27i2/203-216

Renkema, J. (2004). Introduction to discourse studies. Amsterdam/ Philadelphia: John Benjamins Publishing Company.

Sakhiyya, Z. (2017). Negotiating Social Identity through Questions in Casual Conversations: A Critical Discourse Analysis. Indonesian Journal of Applied Linguistics, 6(2), 311-318. https://doi.org/dx.doi.org/10.17509/ijal.v6 i2.4916

Satori, D., \& Komariah, A. (2011). Metodologi penelitian kualitatif. Bandung: Alfabeta.

Suwandi. (2016). Coherence and Cohesion: An Analysis of the Final Project Abstracs of the Undergraduate Students of PGRI Semarang. Indonesian Journal of Applied Linguistics, 5(2), 253-261. https://doi.org/10.17509/ijal.v5i2.1349

Taboada, M. T. (2004). Building Coherence and Cohesion: Task-oriented Dialogue in English and Spanish. Amsterdam/ Philadelphia: John Benjamins Publishing Company.

Tanskanen, S.-K. (2006). Collaborating towards Coherence: Lexical Cohesion in English discourse. Amsterdam/ Philadelphia: John Benjamins Publishing Company.

Yeh, C. (2004). The relationship of cohesion and coherence: A contrastive study of English and Chinese. Journal of Language and Linguistics, 3(2), 243-260.

Zemach, D. ., \& Rumisek, L. . (2003). College Writing: From Paragraph to Essay. Oxford: Macmillan Publisher Limited.

Zemach, D. ., \& Rumisek, L. . (2005). Academic Writing: From Paragraph to Essay. Oxford: Macmillan Publisher. 
DOI: 10.33884/basisupb.v6i1

e-ISSN. 2406 - 9809 p-ISSN. 2527 - 8835
Jurnal Basis Vol. 6 No.l April 2019

English Department - Putera Batam University. 